\title{
Effect of Phosphatic Fertilizer and Biofertilizers on Yield and Quality of Finger Millet (Eleusine coracana $\mathbf{L}$.)
}

\author{
P. Kejiya*, B. Vajantha, M.V.S. Naidu and A.V. Nagavani
}

S.V. Agricultural College, Tirupathi- 517502, Andhra Pradesh, India

*Corresponding author

Keywords

Finger millet,

Phosphorus,

Biofertilizers, Yield

and quality

parameters

Article Info

Accepted:

10 June 2019

Available Online:

10 July 2019

\section{A B S T R A C T}

A field experiment was conducted to study the response of finger millet to phosphorus fertilizer, PSB and VAM during kharif, 2018 on sandy loam soils at Agricultural Research Station, Perumalapalle, Tirupati, Acharya N. G. Ranga Agricultural University, Andhra Pradesh. The experiment was laid out in Randomized Block design with nine treatments and replicated thrice. Among the phosphorus management practices, application of $100 \%$ RDP + PSB @ $750 \mathrm{ml} \mathrm{ha}^{-1}+$ VAM @ $12.5 \mathrm{~kg} \mathrm{ha}^{-1}\left(\mathrm{~T}_{6}\right)$ produced higher dry matter production, yield attributes (plant height, number of tillers $\mathrm{m}^{-2}$, number of earheads $\mathrm{m}^{-2}$, number of fingers earhead and length of earhead1), grain yield and stover yield, grain quality parameters (protein, carbohydrate content) in finger millet. However, it was on par with application of $75 \% \mathrm{RDF}+\mathrm{PSB} @ 750 \mathrm{ml} \mathrm{ha}^{-1}+\mathrm{VAM} @ 12.5 \mathrm{~kg} \mathrm{ha}^{-1}\left(\mathrm{~T}_{9}\right)$. Application of no phosphorus $\left(\mathrm{T}_{1}\right)$, registered the lowest values of yield attributes, yield and grain quality parameters.

\section{Introduction}

Finger millet (Eleusine coracana L.) is an important principal staple food crop grown on marginal and submarginal soils in India.

It is primarly grown in the states of Karnataka, Andhra Pradesh, Odisha and Tamil Nadu in India. It is commonly known as "Nutritious millet" as the grain is nutritionally superior to many cereals providing proteins, minerals, calcium and vitamins in abundance. Straw makes valuable fodder for animals. It contains a low glycemic index and has no gluten, which makes it suitable for diabetes and people with digestive problems, thus considered as a wholesome food for diabetics.

Phosphorus is one of the essential macronutrient for biological growth and proper plant development. Absence of this element in the soil could limit the plant growth and development. A greater part of soil phosphorus is in the form of insoluble phosphates and cannot be utilized by the 
plants. To increase the availability of phosphorus for plants, large amount of fertilizers are being applied to soil. But a large proportion of applied phosphate fertilizer is quickly transformed to insoluble forms which decrease the efficiency of fertilizers. So, there is a need for microbes which have the capacity to solubilize and mobilise phosphorus. Soil phosphates are rendered available either by plant roots or soil microorganism in the rhizosphere through their secretion of organic acids.

Biofertilizers are products of beneficial microorganisms which increase agricultural production by way of nutrient supply. Phosphorus biofertilizers can mobilize unavailable phosphorus pool which can be used by plants. These biofertilizers are inexpensive and simple to use and have no problem of environmental pollution. Thus, judicious use of biofertilizers along with chemical will help to sustain productivity and soil health apart from meeting a part of fertilizer requirement for different crops. Hence, it is very much essential to develop a workable and compatible nutrient management through biofertilizers including the recommended dose of chemical fertilizers, based on scientific facts, local conditions and economic viability.

\section{Materials and Methods}

A field experiment was conducted at of Agriculural Research Station, Perumalapalle, Acharya N. G. Ranga Agricultural University in kharif, 2018. Total rainfall received during the crop growth period was $272.7 \mathrm{~mm}$ in 19 rainy days. The soil of the experimental field was sandy loam in texture with a $\mathrm{pH}$ of 7.6, low in organic carbon $(0.23 \%)$, available $\mathrm{N}$ (120 kg ha-1) and medium in available phosphorus (43 $\mathrm{kg}^{-1}$ ) and available potassium $\left(218 \mathrm{~kg} \mathrm{ha}^{-1}\right)$.

The treatments consisted of nine phosphorus management practices viz., no phosphorus $\left(\mathrm{T}_{1}\right), \quad 100 \%$ Recommended Dose of Phosphorus (RDP) $\left(\mathrm{T}_{2}\right), 125 \%$ RDP $\left(\mathrm{T}_{3}\right)$, $100 \%$ RDP + Phosphorus Solubilising Bacteria@750 ml ha ${ }^{-1}\left(\mathrm{~T}_{4}\right), 100 \%$ RDP + Vesicular Arbuscular Mycorrhizae @ $12.5 \mathrm{~kg}$ $\mathrm{ha}^{-1}\left(\mathrm{~T}_{5}\right), 100 \% \mathrm{RDP}+\mathrm{PSB} @ 750 \mathrm{ml} \mathrm{ha}^{-1}+$ VAM@12.5 kg ha ${ }^{-1}\left(\mathrm{~T}_{6}\right), 75 \% \mathrm{RDP}+\mathrm{PSB}$ @ $750 \mathrm{ml} \mathrm{ha}^{-1}\left(\mathrm{~T}_{7}\right), 75 \% \mathrm{RDP}+\mathrm{VAM} @ 12.5$ $\mathrm{kg} \mathrm{ha}^{-1}\left(\mathrm{~T}_{8}\right)$ and 75\% RDP + PSB@ $@ 750 \mathrm{ml}$ $\mathrm{ha}^{-1}+$ VAM @ $12.5 \mathrm{~kg} \mathrm{ha}^{-1}\left(\mathrm{~T}_{9}\right)$.

The Recommended dose of 60-40-30 kg N, $\mathrm{P}_{2} \mathrm{O}_{5}$ and $\mathrm{K}_{2} \mathrm{O}$ ha $^{-1}$ were applied in the form of urea, single super phosphate (SSP) and muriate of potash (MOP) respectively. Entire quantity of phosphorus, potassium and half of the dose of nitrogen were applied as basal at the time of transplanting and the remaining half of the nitrogen was top dressed at 30 Days after transplanting. The biofertilizers i.e. Liquid Phosphorous Solubilising Bacteria (PSB) @ $750 \mathrm{ml} \mathrm{ha}{ }^{-1}$ and Vesicular Arbuscular Mycorrhizae (VAM) @ 12.5 kg $\mathrm{ha}^{-1}$ were broadcasted in main field each by mixing it with $100 \mathrm{~kg}$ of dried and powdered FYM.

\section{Results and Discussion}

\section{Dry matter production}

Dry matter production of finger millet recorded at flowering and harvest differed significantly with phosphatic fertilizer and biofertilizers. At flowering, significantly the highest dry matter production was recorded with application of $100 \%$ RDP + PSB @ 750 $\mathrm{ml} \mathrm{ha}{ }^{-1}+\mathrm{VAM} @ 12.5 \mathrm{~kg} \mathrm{ha}^{-1}\left(\mathrm{~T}_{6}\right)$ followed by $75 \%$ RDP + PSB @ $750 \mathrm{ml} \mathrm{ha}^{-1}+\mathrm{VAM}$ @ $12.5 \mathrm{~kg} \mathrm{ha}^{-1}\left(\mathrm{~T}_{9}\right)$. At harvest, the highest dry matter production was obtained with $75 \%$ RDP + PSB @ 750 ml ha ${ }^{-1}+$ VAM @ $12.5 \mathrm{~kg}$ $\mathrm{ha}^{-1}\left(\mathrm{~T}_{9}\right)$ which was at par with $100 \%$ RDP + PSB@750 ml ha ${ }^{-1}+$ VAM @ $12.5 \mathrm{~kg} \mathrm{ha}^{-1}$ $\left(\mathrm{T}_{6}\right)$. The treatment no phosphorus $\left(\mathrm{T}_{1}\right)$ was 
received significantly lowest dry matter production.

\section{Yield attributes}

Application of phosphorus fertilizer, PSB and VAM exerted significant influence on number of number of tillers $\mathrm{m}-2$ and number of earheads $\mathrm{m}-2$ at harvest. Among the nine phosphorus management practices, application of $100 \%$ RDP + PSB @ $750 \mathrm{ml} \mathrm{ha}^{-1}+\mathrm{VAM}$ @ $12.5 \mathrm{~kg} \mathrm{ha}^{-1}\left(\mathrm{~T}_{6)}\right.$ registered higher number of number of tillers $\mathrm{m}-2$ and number of earheads $\mathrm{m}^{-2}$ followed by $75 \%$ RDP + PSB @ $750 \mathrm{ml} \mathrm{ha}^{-1}+$ VAM @ $12.5 \mathrm{~kg} \mathrm{ha}^{-1}\left(\mathrm{~T}_{9}\right)$. The yield attributes viz., plant height, number of fingers earhead ${ }^{-1}$ and length of earhead-1 was non-significant effected by treatments. However, taller plant and length of earhead-1 was produced with application of $100 \%$ RDP +PSB@ $@ 750 \mathrm{ml} \mathrm{ha}^{-1}+$ VAM @ $12.5 \mathrm{~kg} \mathrm{ha}^{-1}$ $\left(\mathrm{T}_{6}\right.$ ) while, higher number of fingers earhead ${ }^{-1}$ which was on par with that due to $75 \%$ RDP +PSB@750 ml ha ${ }^{-1}+$ VAM @ $12.5 \mathrm{~kg} \mathrm{ha}^{-1}$ $\left(\mathrm{T}_{9}\right)$. The yield attributes were at their lowest with no phosphorus $\left(T_{1}\right)$ (Table 1$)$.

\section{Grain yield}

The highest grain yield (Table 2 and Fig. 1.) of finger millet was produced with $100 \%$ RDP + PSB @ $750 \mathrm{ml} \mathrm{ha}^{-1}+$ VAM @ $12.5 \mathrm{~kg}$ $\mathrm{ha}^{-1}\left(\mathrm{~T}_{6}\right)$ followed by 75\% RDP + PSB @ 750 $\mathrm{ml} \mathrm{ha}^{-1}+\mathrm{VAM} @ 12.5 \mathrm{~kg} \mathrm{ha}^{-1}\left(\mathrm{~T}_{9}\right)$. The lowest grain yield was recorded with no phosphorus $\left(\mathrm{T}_{1}\right)$.

\section{Straw yield}

The highest straw yield (Table 2 and Fig. 2.) of finger millet was recorded with application of $100 \%$ RDP + PSB @ $750 \mathrm{ml} \mathrm{ha}^{-1}+\mathrm{VAM}$ @ $12.5 \mathrm{~kg} \mathrm{ha}^{-1}\left(\mathrm{~T}_{6}\right)$ which was on par with $125 \%$ RDP $\left(\mathrm{T}_{3}\right)$. The lowest stover yield was recorded with no phosphorus $\left(\mathrm{T}_{1}\right)$.

\section{Grain quality parameters}

\section{Protein content}

All the treatments showed non-significant affect on Protein content in grain (Table 2). Maximum protein content was observed with $75 \%$ RDP + PSB @ $750 \mathrm{ml} \mathrm{ha}^{-1}$ + VAM @ $12.5 \mathrm{~kg} \mathrm{ha}^{-1}\left(\mathrm{~T}_{9}\right)$ while the lowest was noticed with no phosphorus $\left(T_{1}\right)$.

\section{Carbohydrate content}

Carbohydrate content of grain was significantly influenced by treatments. The highest carbohydrate content of finger millet grain (Table 2) was recorded with $75 \% \mathrm{RDF}$ +PSB@750 ml ha ${ }^{-1}+$ VAM @ $12.5 \mathrm{~kg} \mathrm{ha}^{-1}$ $\left(\mathrm{T}_{9}\right)$ which was at par with $75 \% \mathrm{RDF}+\mathrm{PSB}$ @ $750 \mathrm{ml} \mathrm{ha}^{-1}\left(\mathrm{~T}_{7}\right)$. The lowest carbohydrate content was recorded with no phosphorus $\left(\mathrm{T}_{1}\right)$. Higher dry matter production recorded might be due to application of inorganic phosphorus play an important role in metabolic processes and activation of number of enzymes participating in the dark reaction in photosynthesis which in turn increased plant growth and root development. Application of PSB resulted in production of growth promoting substances and there by enhanced the availability of phosphorus and other nutrients in soil. VAM also enhanced the activity of phytohormones like cytokinin and indole acetic acid in plants resulting in better growth and development of plants and Kumar et al., (2017) and Mahdi et al., (2010),

Application of phosphatic biofertilizers along with inorganic phosphorus might have synergistic and additive effect on attributing characters. Phosphorus management had continuous favourable effect on yield attributes, enhanced and steady nutrient release with the application of $100 \% \mathrm{RDP}+$ PSB@750 ml ha ${ }^{-1}+$ VAM @ $12.5 \mathrm{~kg} \mathrm{ha}^{-1}$ $\left(\mathrm{T}_{6}\right)$. 
Table.1 Dry matter production and yield attributes of finger millet as influenced by phosphorus management practices

\begin{tabular}{|c|c|c|c|c|c|c|c|}
\hline \multirow[t]{2}{*}{ Treatments } & \multicolumn{2}{|c|}{$\begin{array}{l}\text { Dry matter } \\
\text { production } \\
\text { kg ha }^{-1}\end{array}$} & \multirow[t]{2}{*}{$\begin{array}{c}\text { Plant } \\
\text { height } \\
(\mathbf{c m})\end{array}$} & \multirow[t]{2}{*}{$\begin{array}{c}\text { Number } \\
\text { of tillers } \\
\mathrm{m}^{-2}\end{array}$} & \multirow[t]{2}{*}{$\begin{array}{c}\text { Number of } \\
\text { earheads } \mathbf{m}^{-2}\end{array}$} & \multirow[t]{2}{*}{$\begin{array}{l}\text { Number of } \\
\text { fingers } \\
\text { earhead }^{-1}\end{array}$} & \multirow[t]{2}{*}{$\begin{array}{c}\text { Length o } \\
\text { earhead } \\
(\mathrm{cm})\end{array}$} \\
\hline & F & $\mathbf{H}$ & & & & & \\
\hline$T_{1}:$ No Phosphorus & $5333^{\mathrm{c}}$ & $7522^{c}$ & 85.65 & $90^{c}$ & $65^{\mathrm{c}}$ & 8 & 9.06 \\
\hline $\begin{array}{l}T_{2}: 100 \% \text { Recommended dose of } \\
\text { Phosphorus (RDP) }\end{array}$ & $5728^{\mathrm{bc}}$ & $8112^{\mathrm{bc}}$ & 87.20 & $100^{\mathrm{ab}}$ & $67^{\mathrm{bc}}$ & 10 & 9.20 \\
\hline $\mathrm{T}_{3}: 125 \% \mathrm{RDP}$ & $5583^{\mathrm{bc}}$ & $7868^{\mathrm{bc}}$ & 85.86 & $96^{\mathrm{bc}}$ & $69^{\mathrm{bc}}$ & 9 & 9.40 \\
\hline $\begin{array}{l}\mathrm{T}_{4}: 100 \% \text { RDP + Phosphorus Solubilizing } \\
\text { Bacteria (PSB) }\end{array}$ & $5661^{\mathrm{bc}}$ & $8556^{\mathrm{b}}$ & 87.86 & $93^{\mathrm{bc}}$ & $68^{\mathrm{bc}}$ & 9 & 9.76 \\
\hline $\begin{array}{l}T_{5}: 100 \% \text { RDP + Vesicular Arbuscular } \\
\text { Mvcorrhizae (VAM) }\end{array}$ & $5728^{\mathrm{bc}}$ & $8000^{\mathrm{bc}}$ & 85.66 & $96^{\mathrm{bc}}$ & $68^{\mathrm{bc}}$ & 9 & 9.55 \\
\hline $\mathrm{T}_{6}: 100 \% \mathrm{RDP}+\mathrm{PSB}+\mathrm{VAM}$ & $6616^{\mathrm{a}}$ & $9473^{\mathrm{a}}$ & 90.60 & $104^{\mathrm{a}}$ & $85^{\mathrm{a}}$ & 10 & 10.13 \\
\hline $\mathrm{T}_{7}: 75 \% \mathrm{RDP}+\mathrm{PSB}$ & $6124^{\mathrm{abc}}$ & $8692^{b}$ & 87.53 & $94^{\mathrm{bc}}$ & $70^{\mathrm{bc}}$ & 10 & 9.73 \\
\hline $\mathrm{T}_{8}: 75 \% \mathrm{RDP}+\mathrm{VAM}$ & $5825^{\mathrm{abc}}$ & $8395^{\mathrm{b}}$ & 85.86 & $101^{\mathrm{a}}$ & $67^{\mathrm{bc}}$ & 9 & 10.06 \\
\hline $\mathrm{T}_{9}: 75 \% \mathrm{RDP}+\mathrm{PSB}+\mathrm{VAM}$ & $6450^{\mathrm{ab}}$ & $9545^{\mathrm{a}}$ & 89.83 & $103^{\mathrm{a}}$ & $74^{\mathrm{b}}$ & 11 & 10.07 \\
\hline F value & $2.71 *$ & $7.35 * *$ & 0.71 & $5.59 * *$ & $35.0 * *$ & 1.10 & 1.19 \\
\hline p-value & 0.042 & 0.000 & 0.677 & 0.002 & 0.000 & 0.411 & 0.360 \\
\hline
\end{tabular}

F: Flowering, H: Harvest

Table.2 Yield and quality parameters of finger millet as influenced by Phosphorus management practices

\begin{tabular}{|c|c|c|c|c|}
\hline Treatments & $\begin{array}{l}\text { Grain } \\
\text { yield } \\
\left(\mathrm{kg} \mathrm{ha}^{-1}\right)\end{array}$ & $\begin{array}{l}\text { Stover } \\
\text { yield } \\
\left(\mathrm{kg} \mathrm{ha}^{-1}\right)\end{array}$ & $\begin{array}{c}\text { Protein } \\
\text { Content } \\
(\%)\end{array}$ & $\begin{array}{c}\text { Carbohydrate } \\
\text { content } \\
(\%)\end{array}$ \\
\hline$T_{1}$ : No Phosphorus & $3692^{\mathrm{d}}$ & $7966^{b}$ & 7.31 & $52.56^{\mathrm{d}}$ \\
\hline $\begin{array}{l}T_{2}: 100 \% \text { Recommended dose of Phosphorus } \\
\text { (RDP) }\end{array}$ & $3846^{\mathrm{bc}}$ & $8382^{\mathrm{a}}$ & 7.44 & $64.80^{\mathrm{ab}}$ \\
\hline $\mathrm{T}_{3}: 125 \%$ RDP & $4083^{\mathrm{abc}}$ & $8545^{\mathrm{a}}$ & 7.54 & $65.76^{\mathrm{a}}$ \\
\hline $\begin{array}{l}\text { T }_{4}: 100 \% \text { RDP + Phosphorus Solubilizing } \\
\text { Bacteria (PSB) }\end{array}$ & $3946^{\mathrm{bc}}$ & $8421^{\mathrm{a}}$ & 7.47 & $59.30^{c}$ \\
\hline $\begin{array}{l}\mathrm{T}_{5}: 100 \% \text { RDP + Vesicular Arbuscular } \\
\text { Mycorrhizae (VAM) }\end{array}$ & $3858^{\mathrm{bc}}$ & $8459^{\mathrm{a}}$ & 7.36 & $60.80^{\mathrm{bc}}$ \\
\hline $\mathrm{T}_{6}: 100 \% \mathrm{RDP}+\mathrm{PSB}+\mathrm{VAM}$ & $4328^{\mathrm{a}}$ & $8614^{\mathrm{a}}$ & 7.59 & $65.56^{\mathrm{a}}$ \\
\hline $\mathrm{T}_{7}: 75 \% \mathrm{RDP}+\mathrm{PSB}$ & $3783^{\mathrm{cd}}$ & $8521^{\mathrm{a}}$ & 7.54 & $68.83^{a}$ \\
\hline $\mathrm{T}_{8}: 75 \% \mathrm{RDP}+\mathrm{VAM}$ & $3942^{\mathrm{bc}}$ & $8514^{\mathrm{a}}$ & 7.45 & $66.90^{\mathrm{a}}$ \\
\hline $\mathrm{T}_{9}: 75 \% \mathrm{RDP}+\mathrm{PSB}+\mathrm{VAM}$ & $4157^{\mathrm{ab}}$ & $8387^{\mathrm{a}}$ & 7.62 & $68.90^{a}$ \\
\hline F value & $3.54 *$ & $3.20 *$ & 0.76 & $13.86 * *$ \\
\hline p-value & 0.015 & 0.023 & 0.636 & 0.000 \\
\hline
\end{tabular}

PSB: liquid PSB $750 \mathrm{ml} \mathrm{ha}^{-1}$, VAM: $12.5 \mathrm{~kg} \mathrm{ha}^{-1}$ 
Fig.1 Grain yield ( $\left.\mathrm{kg} \mathrm{ha}^{-1}\right)$ of finger millet as influenced by phosphorus management practices

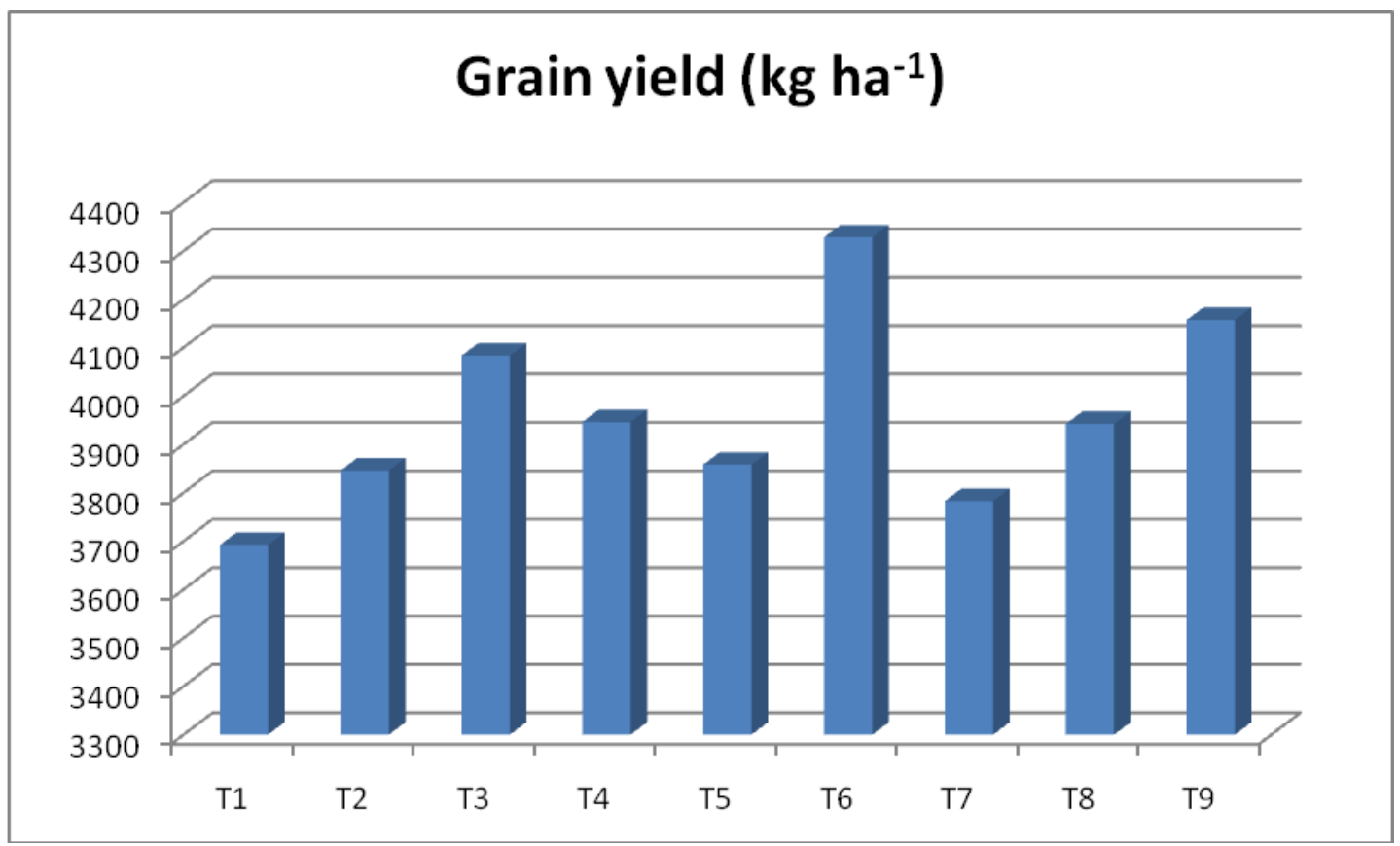

Fig.2 Straw yield ( $\left.\mathrm{kg} \mathrm{ha}^{-1}\right)$ of finger millet as influenced by phosphorus management practices

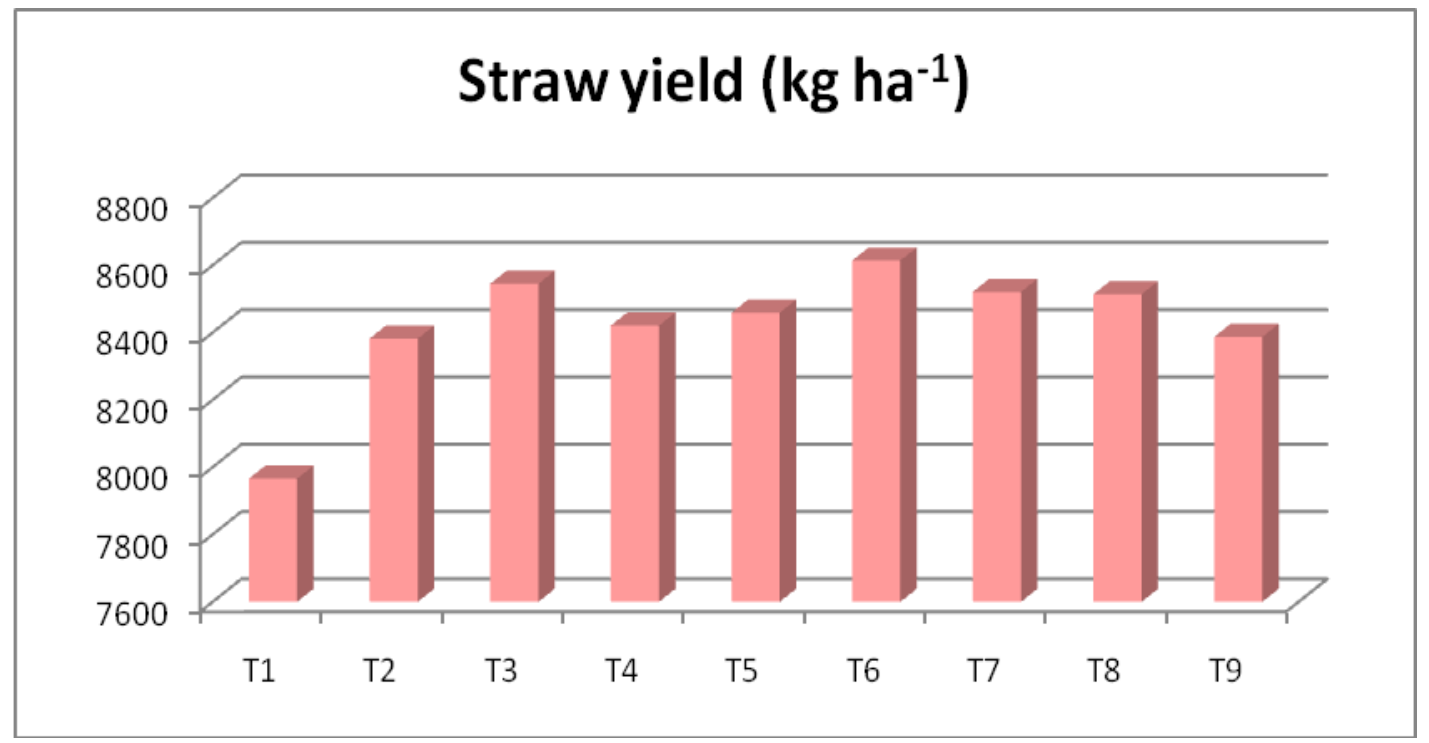

The results are in conformity with that of yield Meena and Gautam (2005) and Divya et al., (2017)

The increase in grain yield of finger millet with might be attributed to better supply of nutrients along with conducive physical environment leading to better root activity and higher nutrient absorption, which resulted in more plant growth and superior yield attributes responsible for higher yield. The application of biofertilizers (PSB and VAM) increased the efficiency of chemical fertilizers due to control release of nutrients in the soil 
through microbial activity which might have facilitates better crop growth (Acharya et al., 2012).

The increased straw yield might be due to addition of inorganic phosphorus and phosphorus solubilizers and mobilizers which may increase the uptake of plant nutrients to manufacture more quality of photosynthates resulting higher straw yield. Furthermore, VAM not only supplies essential nutrients but also water to plants resulting in better growth that led to increasing straw yield. The present findings are in accordance with findings of Pramanik and Bera (2012).

Increased availability of nitrogen in the soil to the plant (through inorganic fertilizers and biofertilizers) might have resulted in increased nitrogen content in seed. It is a well-known fact that nitrogen in seed is directly responsible for higher protein because it is a primary component of amino acid which constitutes the basis of protein.

The present investigations were in agreement with those Meena and Gautam (2005). The lowest grain protein content of finger millet was recorded with no phosphorus $\left(\mathrm{T}_{1}\right)$.

Maximum carbohydrates content was recorded due to combined application of inorganic phosphorus, PSB and VAM helps in increases microbial load in soil which secrete many growth promoting substances which accelerates the physiological processes like synthesis of carbohydrates. The similar results are obtained by Patil et al., (2018). The lowest carbohydrate content of finger millet grain was recorded with no phosphorus $\left(\mathrm{T}_{1}\right)$.

Combined application of $100 \% \mathrm{RDP}+\mathrm{PSB}$ @ $750 \mathrm{ml} \mathrm{ha}^{-1}+\mathrm{VAM} @ 12.5 \mathrm{~kg} \mathrm{ha}^{-1}$ is the most efficient phosphorus management practice for the better growth, yield and quality of finger millet.

\section{Acknowledgment}

Authors are thankful to Acharya N.G. Ranga Agricultural University for providing necessary facilities. Also special thanks to Department of Soil Science and Agricultural Chemistry, S. V. Agricultural College, Tirupati.

\section{References}

Acharya, R., Dash, A. K and Senapati, H. K. 2012. Effect of integrated nutrient management on microbial activity influencing grain yield under rice-rice cropping system in an acid soils. Asian Journal of Microbiology, Biotechnology and Environmental Sciences. 14: 365368.

Divya, G., Vani, K.P., Babu, P.S and Devi, K.B.S. 2017. Yield attributes and yield of summer pearlmillet as influenced by cultivars and integrated nutrient management. International Journal of Current Microbiology and Applied Sciences. 6(10): 1491-1495.

Kumar, S. K., Rao, Ch. P., Rekha M. S and Prasad, P. R. 2017. Growth and yield of finger millet (Eleusine coracana L.) as influenced by phosphorus management practices. The Andhra Agricultural Journal. 64(1): 40-45.

Mahdi, S. S., Hassan, G. I., Samoon, S. A., Rather, H. A., Dar, S. A and Zehra, B. 2010. Biofertilizers in organic agriculture. Journal of Phytology, 2 (10): 42-54.

Meena, R and Gautam, R. C. 2005. Effect of integrated nutrient management on productivity, nutrient uptake and moisture use functions of pearlmillet. Indian Journal of Agronomy. 50(4): 305-307.

Michaelraj P. S. J and Shanmugam A, 2013. A study on millets base cultivation and consumption in India. International 
Journal of Marketing, Financial Services \& Management Research. 2(4): 2277-3622.

Patil, P., Nagamani, C., Reddy, A. P. K and Umamahesh, V. 2018. Effect of integrated nutrient management on yield attributes, yield and quality of pearl millet [Pennisetum glaucum (L.) R. br. emend. Stuntz]. International Journal of Chemical Studies. 6(4): 1098-1101.

Pramanik, K and Bera, A. K. 2012. Response of biofertilizers and phytohormones on growth and yield of chickpea (Cicer arientinum L.). Journal of Crop and Weed. 8(2): 45-49.

\section{How to cite this article:}

Kejiya, P., B. Vajantha, M.V.S. Naidu and Nagavani, A.V. 2019. Effect of Phosphatic Fertilizer and Biofertilizers on Yield and Quality of Finger Millet (Eleusine coracana L.). Int.J.Curr.Microbiol.App.Sci. 8(07): 846-852. doi: https://doi.org/10.20546/ijcmas.2019.807.101 